\title{
HIV Testing Among Transgender Women and Men - 27 States and Guam, 2014-2015
}

\author{
Marc A. Pitasi, $\mathrm{MPH}^{1}$; Emeka Oraka, $\mathrm{MPH}^{1}$; Hollie Clark, $\mathrm{MPH}^{1}$; Machell Town, $\mathrm{PhD}^{2}$; Elizabeth A. DiNenno, $\mathrm{PhD}^{1}$
}

Transgender persons are at high risk for human immunodeficiency virus (HIV) infection; in a recent analysis of the results of over nine million CDC funded HIV tests, transgender women* had the highest percentage of confirmed positive results $(2.7 \%)$ of any gender category $(1)$. Transgender men, ${ }^{\dagger}$ particularly those who have sex with cisgender ${ }^{\S}$ men, are also at high risk for infection (2). HIV testing is critical for detecting and treating persons who are infected and delivering preventive services to those who are uninfected. CDC recommends that persons at high risk for HIV infection be screened for HIV at least annually, although transgender persons are not specified in the current recommendations. CDC analyzed data from the Behavioral Risk Factor Surveillance System (BRFSS) to describe HIV testing among transgender women and men and two cisgender comparison groups in 27 states and Guam. After adjusting for demographic characteristics, transgender women and men had a lower prevalence of ever testing and past year testing for HIV $(35.6 \%$ and $31.6 \%$ ever, and $10.0 \%$ and $10.2 \%$ past year, respectively) compared with cisgender gay and bisexual men $(61.8 \%$ ever and $21.6 \%$ past year) and instead reported testing at levels comparable to cisgender heterosexual men and women (35.2\% ever, and $8.6 \%$ past year). This finding suggests that transgender women and men might not be sufficiently reached by current HIV testing measures. Tailoring HIV testing activities to overcome the unique barriers faced by transgender women and men might increase rates of testing among these populations.

BRFSS is an annual, state-based, random-digit-dialed cellular and landline telephone survey of the noninstitutionalized U.S. adult population. ${ }^{9}$ Gender identity was uniformly assessed in an optional module used by 20 jurisdictions** in 2014 and 22 jurisdictions ${ }^{\dagger \dagger}$ in 2015. Fourteen jurisdictions participated in the module during both years, six participated only in 2014, and eight participated only in 2015, for a total

\footnotetext{
* Persons assigned male sex at birth who identify as woman, transgender woman, or another transfeminine identity.

$\dagger$ Persons assigned female sex at birth who identify as man, transgender man, or another transmasculine identity.

$\$$ Persons whose sex assigned at birth is the same as their gender identity or expression.

I https://www.cdc.gov/brfss/.

** Delaware, Guam, Hawaii, Idaho, Indiana, Iowa, Kansas, Kentucky, Louisiana, Maryland, Minnesota, Montana, Nevada, New York, Ohio, Pennsylvania, Vermont, Virginia, Wisconsin, and Wyoming.

$\dagger \dagger$ Colorado, Connecticut, Delaware, Georgia, Hawaii, Idaho, Illinois, Indiana, Iowa, Kansas, Maryland, Massachusetts, Minnesota, Missouri, Nevada, New York, Ohio, Pennsylvania, Texas, Virginia, West Virginia, and Wisconsin.
}

of 28. Jurisdiction-specific response rates ranged from 33.0\% to $59.2 \% \$$ and $34.4 \%$ to $57.6 \% 99$ in 2014 and 2015 , respectively. Transgender respondents were defined as those who answered affirmative to the question if they considered themselves to be transgender. Those who answered affirmative were asked to identify as male-to-female (defined as transgender women in this report), female-to-male (defined as transgender men in this report), or gender nonconforming. Because of small sample size, responses from gender nonconforming persons $(\mathrm{n}=272)$ were not included in this analysis.

Pooled data collected in 2014 and 2015 were used to compare demographic characteristics and HIV testing among transgender and cisgender respondents. Cisgender men who reported sexual orientations of gay or bisexual represent a group at high risk for HIV infection (3). Cisgender men and women who reported an orientation of straight (hereafter referred to as cisgender heterosexual men and women) represent a group at lower risk for infection (4). The proportion of respondents who reported ever and past year HIV testing was calculated, and unadjusted prevalence ratios and 95\% confidence intervals were estimated to identify characteristics associated with ever testing among transgender women and men. Multivariable logistic regression models compared self-reported prevalence of ever and past year testing among transgender women and men with cisgender gay and bisexual men while adjusting for characteristics associated with testing in univariate models $(\mathrm{p}<0.10)$. All estimates were weighted to account for the complex multistage sampling design; because only 14 of 28 jurisdictions participated in the optional module during both years of data collection, weights for these 14 jurisdictions were averaged across the 2-year period to account for varying levels of participation over time. Estimates with relative standard error $\geq 30 \%$ were not reported.

During 2014-2015, 28 jurisdictions collected data on gender identity, resulting in a total sample of 732 transgender women, 451 transgender men, 3,798 cisgender gay and bisexual men, and 301,524 cisgender heterosexual men and women (Table 1). The unadjusted prevalence of ever testing for HIV was $37.5 \%$ among transgender women, $36.6 \%$ among transgender men, $66.2 \%$ among cisgender gay and bisexual men, and $35.2 \%$ among cisgender

\footnotetext{
$\$ \$$ https://www.cdc.gov/brfss/annual_data/2014/pdf/2014_dqr.pdf.

99 https://www.cdc.gov/brfss/annual_data/2015/pdf/2015-sdqr.pdf.
} 
TABLE 1. Selected demographic characteristics and HIV testing behaviors among transgender and cisgender respondents* — Behavioral Risk Factor Surveillance System, 27 states and Guam, ${ }^{\dagger}$ 2014-2015

\begin{tabular}{|c|c|c|c|c|c|c|c|c|}
\hline \multirow[b]{2}{*}{ Characteristic } & \multicolumn{2}{|c|}{ Transgender women } & \multicolumn{2}{|c|}{ Transgender men } & \multicolumn{2}{|c|}{$\begin{array}{l}\text { Cisgender gay and } \\
\text { bisexual men } \\
\S\end{array}$} & \multicolumn{2}{|c|}{$\begin{array}{l}\text { Cisgender heterosexual } \\
\text { men and women? }\end{array}$} \\
\hline & No. & $\% * *(95 \% \mathrm{Cl})$ & No. & $\% * *(95 \% \mathrm{Cl})$ & No. & $\% * *(95 \% \mathrm{Cl})$ & No. & $\% * *(95 \% \mathrm{Cl})$ \\
\hline Total & 732 & $100-$ & 451 & $100(-)$ & 3,798 & $100(-)$ & 301,524 & $100(-)$ \\
\hline \multicolumn{9}{|l|}{ Race/Ethnicity } \\
\hline White, non-Hispanic & 527 & $60.6(52.8-67.9)$ & 309 & $49.2(37.9-60.6)$ & 2,929 & $67.1(63.7-70.3)$ & 242,370 & $71.1(70.7-71.5)$ \\
\hline Black, non-Hispanic & 67 & $13.3(9.3-18.7)$ & 43 & $11.4(6.6-18.9)$ & 233 & $11.8(9.7-14.5)$ & 21,166 & $12.0(11.7-12.3)$ \\
\hline Hispanic or Latino & 46 & $13.2(8.1-21.0)$ & 48 & $29.0(18.6-42.2)$ & 250 & $12.8(10.2-15.8)$ & 14,320 & $11.0(10.7-11.4)$ \\
\hline Other, non-Hispanic & 77 & $12.9(7.9-20.2)$ & 42 & $-\dagger+$ & 338 & $8.3(6.9-10.1)$ & 19,890 & $5.9(5.7-6.1)$ \\
\hline \multicolumn{9}{|l|}{ Age group (yrs) } \\
\hline $18-24$ & 55 & $14.2(9.9-19.8)$ & 30 & $15.6(8.7-26.4)$ & 434 & $21.9(19.0-25.1)$ & 14,166 & 11.7 (11.4-12.0) \\
\hline $25-44$ & 146 & $29.1(22.3-37.0)$ & 98 & $45.2(33.7-57.2)$ & 893 & $33.4(30.5-36.5)$ & 60,098 & 31.5 (31.1-31.9) \\
\hline $45-64$ & 322 & $40.3(33.6-47.4)$ & 185 & $25.0(18.3-33.1)$ & 1,582 & $33.9(31.2-36.7)$ & 122,321 & $36.2(35.9-36.6)$ \\
\hline$\geq 65$ & 209 & $16.4(12.6-21.1)$ & 138 & $14.2(10.0-19.8)$ & 889 & $10.8(9.5-12.3)$ & 104,939 & $20.6(20.4-20.8)$ \\
\hline \multicolumn{9}{|l|}{ Education } \\
\hline$<$ High school & 90 & $22.0(15.8-29.9)$ & 72 & $34.4(23.5-47.1)$ & 180 & $10.4(8.2-12.9)$ & 19,081 & $12.2(11.9-12.5)$ \\
\hline High school & 292 & $38.5(32.0-45.4)$ & 169 & $40.6(29.9-52.2)$ & 813 & $25.4(22.5-28.5)$ & 86,020 & $29.7(29.4-30.1)$ \\
\hline Some college & 205 & $24.2(18.6-30.9)$ & 116 & $15.1(10.2-21.8)$ & 996 & $31.5(28.6-34.5)$ & 82,460 & $31.1(30.7-31.5)$ \\
\hline College or above & 142 & $15.3(11.3-20.4)$ & 92 & $10.0(6.5-15.0)$ & 1,801 & $32.8(30.2-35.5)$ & 113,289 & $27.0(26.7-27.3)$ \\
\hline \multicolumn{9}{|l|}{ Annual household income } \\
\hline$<\$ 25,000$ & 240 & $40.1(33.0-47.6)$ & 149 & $30.4(21.7-40.8)$ & 950 & $25.5(22.9-28.3)$ & 64,039 & $22.3(21.9-22.6)$ \\
\hline$\$ 25,000-\$ 49,999$ & 169 & $20.9(15.6-27.4)$ & 118 & $29.4(19.7-41.4)$ & 886 & $21.7(19.2-24.4)$ & 66,938 & $21.3(21.0-21.7)$ \\
\hline$\geq \$ 50,000$ & 232 & $29.5(23.8-35.9)$ & 120 & $24.4(15.0-37.0)$ & 1,604 & $40.1(37.2-43.1)$ & 128,546 & $42.8(42.4-43.1)$ \\
\hline Missing & 91 & $9.6(6.4-14.0)$ & 64 & $15.8(10.0-24.1)$ & 358 & $12.8(10.4-15.6)$ & 42,001 & $13.7(13.4-13.9)$ \\
\hline \multicolumn{9}{|l|}{ Has health insurance } \\
\hline Yes & 649 & $80.7(72.7-86.8)$ & 394 & $70.6(57.1-81.2)$ & 3,446 & $88.2(86.1-90.1)$ & 280,774 & $88.8(88.5-89.1)$ \\
\hline No & 73 & $19.3(13.2-27.4)$ & 54 & $29.5(18.8-42.9)$ & 338 & $11.8(9.9-13.9)$ & 19,804 & $11.2(10.9-11.5)$ \\
\hline \multicolumn{9}{|l|}{ Marital status } \\
\hline Married or unmarried couple & 383 & $52.2(45.0-59.2)$ & 219 & $53.1(41.8-64.1)$ & 1,302 & $33.2(30.5-36.1)$ & 172,305 & $57.3(56.9-57.7)$ \\
\hline Separated/widowed/ divorced & 184 & $19.7(15.0-25.5)$ & 138 & $18.5(12.4-26.8)$ & 551 & $10.6(8.9-12.6)$ & 85,996 & $20.5(20.2-20.8)$ \\
\hline Never married & 161 & $28.1(22.3-34.7)$ & 90 & $28.4(19.7-39.0)$ & 1,918 & $56.2(53.1-59.2)$ & 41,852 & $22.2(21.8-22.5)$ \\
\hline \multicolumn{9}{|l|}{ Geographic region } \\
\hline Northeast & 111 & $21.5(16.7-27.2)$ & 48 & $16.3(10.7-24.0)$ & 904 & $30.3(27.8-33.0)$ & 50,129 & $25.6(25.3-25.8)$ \\
\hline Midwest & 309 & $36.2(29.9-43.0)$ & 206 & $34.5(24.9-45.5)$ & 1,358 & $29.2(26.6-31.9)$ & 122,255 & $33.0(32.7-33.2)$ \\
\hline South & 186 & $37.1(29.8-45.0)$ & 133 & $42.4(31.1-54.6)$ & 907 & $32.0(28.7-35.4)$ & 77,703 & $33.8(33.5-34.1)$ \\
\hline West & 114 & $5.3(3.9-7.2)$ & 58 & $6.8(4.2-10.7)$ & 595 & $8.5(7.4-9.8)$ & 49,389 & $7.7(7.6-7.8)$ \\
\hline \multicolumn{9}{|l|}{ County of residence } \\
\hline Metropolitan & 484 & $77.3(71.3-82.4)$ & 304 & $80.3(71.7-86.8)$ & 3,020 & $87.4(85.2-89.3)$ & 210,875 & $81.5(81.3-81.7)$ \\
\hline Nonmetropolitan & 236 & $22.7(17.6-28.7)$ & 141 & $19.7(13.2-28.3)$ & 744 & $12.6(10.7-14.8)$ & 88,601 & $18.5(18.3-18.7)$ \\
\hline \multicolumn{9}{|c|}{ Ever received diagnosis of depressive disorder } \\
\hline Yes & 149 & $21.9(16.8-28.1)$ & 116 & $22.6(15.2-32.1)$ & 1,156 & $30.9(28.0-34.0)$ & 56,693 & $18.0(17.7-18.3)$ \\
\hline No & 577 & $78.1(71.9-83.2)$ & 331 & $77.4(67.9-84.8)$ & 2,619 & $69.1(66.0-72.1)$ & 243,693 & $82.0(81.7-82.3)$ \\
\hline \multicolumn{9}{|l|}{ Ever tested for HIV } \\
\hline Yes & 225 & $37.5(30.8-44.6)$ & 137 & $36.6(27.0-47.4)$ & 2,506 & $66.2(63.3-69.1)$ & 80,241 & $35.2(34.8-35.5)$ \\
\hline No & 499 & $62.6(55.4-69.2)$ & 302 & $63.4(52.6-73.0)$ & 1,247 & $33.8(30.9-36.7)$ & 211,990 & $64.8(64.5-65.2)$ \\
\hline \multicolumn{9}{|l|}{ Tested for HIV in past 12 months } \\
\hline Yes & 65 & 11.7 (7.9-16.9) & 29 & $12.4(6.8-21.5)$ & 895 & $27.5(24.9-30.3)$ & 15,118 & $8.6(8.4-8.9)$ \\
\hline No & 667 & $88.3(83.1-92.1)$ & 422 & $87.6(78.5-93.2)$ & 2,903 & $72.5(69.7-75.1)$ & 286,406 & $91.4(91.1-91.6)$ \\
\hline \multicolumn{9}{|l|}{ Setting of last HIV test } \\
\hline Private doctor/HMO/clinic & 136 & $58.9(47.4-69.6)$ & 91 & $61.4(44.9-75.6)$ & 1,651 & $65.1(61.4-68.7)$ & 53,626 & $69.6(69.0-70.3)$ \\
\hline Hospital (inpatient and ED) & 34 & $14.5(8.1-24.5)$ & 25 & $13.5(7.5-23.1)$ & 222 & $9.2(7.4-11.4)$ & 9,498 & $12.0(11.6-12.5)$ \\
\hline Other§§ & 51 & $26.7(17.9-37.8)$ & 20 & -†† & 605 & $25.6(22.3-29.3)$ & 15,606 & $18.4(17.8-18.9)$ \\
\hline
\end{tabular}

Abbreviations: $\mathrm{Cl}$ = confidence interval; $\mathrm{ED}=$ emergency department; $\mathrm{HIV}=$ human immunodeficiency virus; $\mathrm{HMO}=$ health maintenance organization.

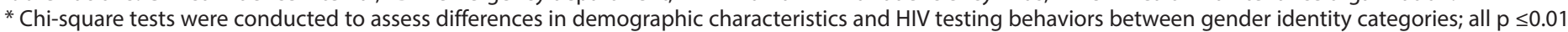
(data not shown).

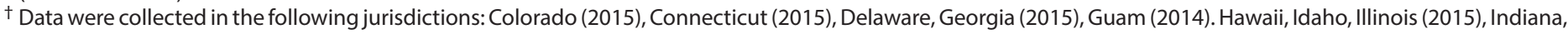

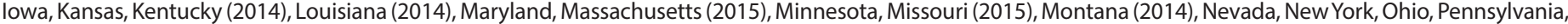

Texas (2015), Vermont (2014), Virginia, West Virginia (2015), Wisconsin, and Wyoming (2014).

Includes cisgender men and women who reported a sexual orientation of straight.

** Weighted column percent excludes missing values and responses of don't know, not sure, or not asked unless otherwise noted.

†† Estimate suppressed because relative standard error of the estimate was $\geq 30 \%$.

$\$ \$$ Includes counseling and testing sites, correctional facilities, drug treatment facilities, at home, or somewhere else. 
heterosexual men and women. The unadjusted prevalence of past year testing was $11.7 \%$ among transgender women, $12.4 \%$ among transgender men, $27.5 \%$ among cisgender gay and bisexual men, and $8.6 \%$ among cisgender heterosexual men and women.

Black transgender women (62.6\%) and men (66.9\%) had a higher prevalence of ever testing than their white counterparts (33.2\% and $30.7 \%$, respectively). Among transgender women, the highest prevalence of ever testing $(68.5 \%)$ was reported by those who had ever received a diagnosis of a depressive disorder (Table 2). After adjusting for demographic characteristics, transgender women and men had a lower prevalence of ever testing and past year testing for HIV (35.6\% and 31.6\% ever, and $10.0 \%$ and $10.2 \%$ past year, respectively) compared with cisgender gay and bisexual men $(61.8 \%$ ever, and $21.6 \%$ past year) and reported testing at levels comparable with those of cisgender heterosexual men and women $(35.2 \%$ ever, and 8.6\% past year) (Table 3).

TABLE 2. Prevalence of ever testing for HIV by demographic characteristics among transgender women and men — Behavioral Risk Factor Surveillance System, 27 states and Guam, ${ }^{*} 2014-2015$

\begin{tabular}{|c|c|c|c|c|}
\hline \multirow[b]{2}{*}{ Characteristic } & \multicolumn{2}{|c|}{ Transgender women } & \multicolumn{2}{|c|}{ Transgender men } \\
\hline & $\begin{array}{c}\% \text { Ever tested }^{\dagger} \\
(95 \% \mathrm{Cl})\end{array}$ & $\begin{array}{c}\text { PR } \\
(95 \% \mathrm{Cl})\end{array}$ & $\begin{array}{c}\% \text { Ever tested }^{\dagger} \\
(95 \% \mathrm{Cl})\end{array}$ & $\begin{array}{c}\mathrm{PR} \\
(95 \% \mathrm{Cl})\end{array}$ \\
\hline $\begin{array}{l}\text { Race/Ethnicity } \\
\text { White, non-Hispanic } \\
\text { Black, non-Hispanic } \\
\text { Hispanic or Latino } \\
\text { Other, non-Hispanic }\end{array}$ & $\begin{array}{r}33.2(25.7-41.6) \\
62.6(45.2-77.3) \\
-\S \\
-\S\end{array}$ & $\begin{array}{c}\text { Ref } \\
1.9(1.3-2.7) \\
1.0(0.5-2.0) \\
0.9(0.4-1.9)\end{array}$ & $\begin{array}{r}30.7(21.9-41.2) \\
66.9(42.8-84.6) \\
-\S \\
-\S\end{array}$ & $\begin{array}{c}\text { Ref } \\
2.2(1.4-3.4) \\
1.3(0.7-2.6) \\
0.5(0.1-2.2)\end{array}$ \\
\hline $\begin{array}{l}\text { Age group (yrs) } \\
18-24 \\
25-44 \\
45-64 \\
\geq 65\end{array}$ & $\begin{array}{r}34.7(19.9-53.2) \\
54.4(38.1-69.9) \\
35.1(25.8-45.7) \\
14.7(8.1-25.2)\end{array}$ & $\begin{array}{l}0.6(0.4-1.1) \\
\quad \text { Ref } \\
0.6(0.4-1.0) \\
0.3(0.1-0.5)\end{array}$ & $\begin{array}{r}53.6(25.6-79.6) \\
40.2(23.4-59.6) \\
36.2(23.9-50.6) \\
-\S\end{array}$ & $\begin{array}{l}1.3(0.6-2.8) \\
\text { Ref } \\
0.9(0.5-1.7) \\
0.2(0.1-0.4)\end{array}$ \\
\hline $\begin{array}{l}\text { Education } \\
\text { <High school } \\
\text { High school } \\
\text { Some college } \\
\text { College or above }\end{array}$ & $\begin{array}{l}36.4(21.4-54.6) \\
37.6(27.5-49.0) \\
39.3(26.9-53.2) \\
35.1(22.1-50.9)\end{array}$ & $\begin{array}{l}1.0(0.6-1.7) \\
\quad \text { Ref } \\
1.0(0.7-1.6) \\
0.9(0.6-1.6)\end{array}$ & $\begin{array}{r}-\S \\
38.0(23.0-55.8) \\
28.4(17.4-42.7) \\
58.9(40.9-74.8)\end{array}$ & $\begin{array}{l}0.9(0.4-1.9) \\
\quad \operatorname{Ref} \\
0.8(0.4-1.4) \\
1.6(0.9-2.7)\end{array}$ \\
\hline $\begin{array}{l}\text { Annual household income } \\
<\$ 25,000 \\
\$ 25,000-\$ 49,999 \\
\geq \$ 50,000\end{array}$ & $\begin{array}{l}41.8(30.4-54.1) \\
35.4(21.8-51.9) \\
32.1(21.8-44.5)\end{array}$ & $\begin{array}{l}1.2(0.7-2.0) \\
\quad \text { Ref } \\
0.9(0.5-1.6)\end{array}$ & $\begin{array}{r}51.5(34.4-68.2) \\
32.8(17.3-53.1) \\
-\S\end{array}$ & $\begin{array}{l}1.6(0.8-3.0) \\
\quad \operatorname{Ref} \\
0.7(0.3-1.7)\end{array}$ \\
\hline $\begin{array}{l}\text { Has health insurance } \\
\text { Yes } \\
\text { No }\end{array}$ & $\begin{array}{l}36.4(29.5-43.9) \\
40.2(22.3-61.1)\end{array}$ & $\begin{array}{c}\text { Ref } \\
1.1(0.6-1.9)\end{array}$ & $\begin{array}{r}39.1(28.7-50.7) \\
-\S\end{array}$ & $\begin{array}{c}\text { Ref } \\
0.8(0.4-1.7)\end{array}$ \\
\hline $\begin{array}{l}\text { Marital status } \\
\text { Married or unmarried couple } \\
\text { Separated/widowed/divorced } \\
\text { Never married }\end{array}$ & $\begin{array}{l}31.3(22.4-41.8) \\
44.0(30.6-58.4) \\
44.5(32.5-57.2)\end{array}$ & $\begin{array}{c}\text { Ref } \\
1.4(0.9-2.2) \\
1.4(0.9-2.2)\end{array}$ & $\begin{array}{l}25.0(15.1-38.5) \\
47.8(28.2-68.1) \\
49.9(31.6-68.3)\end{array}$ & $\begin{array}{c}\text { Ref } \\
1.9(1.0-3.7) \\
2.0(1.1-3.7)\end{array}$ \\
\hline $\begin{array}{l}\text { Geographic region } \\
\text { Northeast } \\
\text { Midwest } \\
\text { South } \\
\text { West }\end{array}$ & $\begin{array}{l}33.4(22.3-46.6) \\
35.7(25.9-46.8) \\
41.2(28.3-55.6) \\
39.8(27.0-54.1)\end{array}$ & $\begin{array}{c}\text { Ref } \\
1.1(0.7-1.7) \\
1.2(0.8-2.0) \\
1.2(0.7-2.0)\end{array}$ & $\begin{array}{l}38.5(20.9-59.8) \\
36.6(21.1-55.5) \\
35.5(20.6-53.8) \\
39.9(20.7-62.8)\end{array}$ & $\begin{array}{c}\text { Ref } \\
1.0(0.5-2.0) \\
0.9(0.5-1.9) \\
1.0(0.5-2.2)\end{array}$ \\
\hline $\begin{array}{l}\text { County of residence } \\
\text { Metropolitan } \\
\text { Nonmetropolitan }\end{array}$ & $\begin{array}{l}35.9(28.5-44.1) \\
42.7(29.7-56.8)\end{array}$ & $\begin{array}{c}\text { Ref } \\
1.2(0.8-1.8)\end{array}$ & $\begin{array}{r}40.4(28.6-53.4) \\
-\S\end{array}$ & $\begin{array}{c}\text { Ref } \\
0.5(0.3-1.1)\end{array}$ \\
\hline $\begin{array}{l}\text { Ever received diagnosis of dep } \\
\text { Yes } \\
\text { No }\end{array}$ & $\begin{array}{l}68.5(54.7-79.6) \\
28.5(21.8-36.4)\end{array}$ & $\begin{array}{c}2.4(1.8-3.3) \\
\text { Ref }\end{array}$ & $\begin{array}{l}40.4(23.9-59.4) \\
34.9(23.8-47.9)\end{array}$ & $\begin{array}{c}1.2(0.7-2.1) \\
\text { Ref }\end{array}$ \\
\hline
\end{tabular}

Abbreviations: $\mathrm{Cl}$ = confidence interval; $\mathrm{HIV}=$ human immunodeficiency virus; $\mathrm{PR}=$ prevalence ratio; Ref = reference category.

* Data were collected in the following jurisdictions: Colorado (2015), Connecticut (2015), Delaware, Georgia (2015), Guam (2014), Hawaii, Idaho, Illinois (2015), Indiana, lowa, Kansas, Kentucky (2014), Louisiana (2014), Maryland, Massachusetts (2015), Minnesota, Missouri (2015), Montana (2014), Nevada, New York, Ohio, Pennsylvania, Texas (2015), Vermont (2014), Virginia, West Virginia (2015), Wisconsin, and Wyoming (2014).

† Percentage is weighted and excludes missing values and responses of don't know, not sure, not asked.

$\S$ Estimate suppressed because relative standard error of the estimate was $\geq 30 \%$. 
TABLE 3. Prevalence of ever testing and testing in past 12 months for HIV, by gender identity category - Behavioral Risk Factor Surveillance System, 27 states and Guam, ${ }^{*}$ 2014-2015

\begin{tabular}{|c|c|c|c|c|}
\hline \multirow[b]{2}{*}{ Gender identity category } & \multicolumn{2}{|c|}{ Ever tested for HIV } & \multicolumn{2}{|c|}{ Tested in past 12 months for HIV } \\
\hline & $\begin{array}{c}\text { Adjusted prevalence } \\
(95 \% \mathrm{Cl})\end{array}$ & $\begin{array}{c}\mathrm{aPR}^{\uparrow} \\
(95 \% \mathrm{Cl})\end{array}$ & $\begin{array}{c}\text { Adjusted prevalence } \\
(95 \% \mathrm{Cl})\end{array}$ & $\begin{array}{c}\mathrm{aPR}^{\mathrm{I}} \\
(95 \% \mathrm{Cl})\end{array}$ \\
\hline Transgender women & $35.6(29.2-42.6)$ & $0.6(0.5-0.7)$ & $10.0(6.5-15.0)$ & $0.5(0.3-0.7)$ \\
\hline Transgender men & $31.6(22.5-42.4)$ & $0.5(0.4-0.7)$ & $10.2(5.8-17.5)$ & $0.5(0.3-0.8)$ \\
\hline Cisgender gay and bisexual men ${ }^{\dagger}$ & $61.8(59.0-64.6)$ & Ref & $21.6(19.4-24.0)$ & Ref \\
\hline Cisgender heterosexual men and women ${ }^{\S}$ & $35.2(34.8-35.6)$ & $0.6(0.5-0.6)$ & $8.6(8.4-8.9)$ & $0.4(0.4-0.5)$ \\
\hline \multicolumn{5}{|c|}{$\begin{array}{l}\text { Abbreviations: aPR = adjusted prevalence ratio; } \mathrm{Cl}=\text { confidence interval; HIV = human immunodeficiency virus; Ref = reference category. } \\
\text { * Data were collected in the following jurisdictions: Colorado (2015), Connecticut (2015), Delaware, Georgia (2015), Guam (2014), Hawaii, Idaho, Illinois (2015), Indiana, } \\
\text { lowa, Kansas, Kentucky (2014), Louisiana (2014), Maryland, Massachusetts (2015), Minnesota, Missouri (2015), Montana (2014), Nevada, New York, Ohio, Pennsylvania, } \\
\text { Texas (2015), Vermont (2014), Virginia, West Virginia (2015), Wisconsin, and Wyoming (2014). } \\
+ \text { Includes cisgender men who reported a sexual orientation of gay or bisexual. } \\
\text { § Includes cisgender men and women who reported a sexual orientation of straight. } \\
\text { ^ Adjusted for: race/ethnicity, age, education, annual household income, health insurance, marital status, geographic region, metropolitan county of residence, ever } \\
\text { diagnosed with depressive disorder. }\end{array}$} \\
\hline
\end{tabular}

\section{Discussion}

Despite the high risk for HIV infection previously reported among transgender populations, nearly two thirds of transgender women and men in the sample reported never testing for HIV, which is consistent with evidence suggesting that many HIVinfected transgender women are not aware of their status (5). The prevalences of ever and past year testing among transgender women and men were comparable to those among cisgender heterosexual men and women, a group at much lower risk for infection. Transgender women and men reported a substantially lower prevalence of ever and past year testing than did cisgender gay and bisexual men. These findings indicate that current selfreported HIV testing levels among transgender women and men are inconsistent with their HIV risk profiles. Innovative, tailored approaches might be needed to reach transgender persons who are not being reached by existing HIV prevention strategies that focus on other key populations, such as gay, bisexual, and other men who have sex with men.***

Black transgender women and men were more likely than their white counterparts to report ever testing, which might reflect success of expanded testing measures focused among black communities $(\sigma)$ or might be a response to racial/ethnic disparities in HIV infection reported among transgender women $(1,5)$. Transgender women who ever received a diagnosis of depressive disorder were more likely than those who had not to report ever testing; this is consistent with previous findings in the U.S. general population (7). However, few other differences in testing prevalence across demographic subgroups were identified, indicating widespread opportunities for improvement of testing measures aimed toward all transgender women and men who are at risk for HIV infection. Such measures should account for the unique barriers to testing that many transgender persons might face, such as

\footnotetext{
${ }^{* * *}$ https://effectiveinterventions.cdc.gov/en.
}

HIV stigma within the transgender community (8), gender identity stigma in health care settings (9), and socioeconomic marginalization (10)

The findings in this report are subject to at least four limitations. First, the proportion of transgender respondents was small $(<1 \%)$, which reduced the precision of HIV testing estimates. Second, BRFSS transgender data are only representative of transgender persons in the 28 jurisdictions that participated in the optional module and therefore cannot be generalized to the entire U.S. transgender population. Third, the measure of gender identity might incorrectly classify transgender respondents who self-identify simply as man or woman rather than transgender man or woman, which would potentially underestimate the number of transgender persons in the sample. Finally, because BRFSS does not ask questions about HIV status or sexual risk behaviors, the analytic sample might have included respondents who are already living with HIV infection or who are not at risk for HIV infection and therefore would be less likely to have tested for HIV in the past year or at all.

The findings of this analysis indicate suboptimal rates of HIV testing among transgender women and men. The population-based estimates in this report can serve as a baseline for future monitoring of testing trends among transgender persons. Intensified and expanded use of culturally appropriate recruitment methods by public health officials might enhance activities to reach transgender women and men and increase the rates of testing. CDC is currently working to enhance the capacity of community-based organizations to provide targeted HIV testing in addition to other prevention and support services to transgender persons who are at risk for or have newly diagnosed HIV. These programs and other innovative approaches are needed to improve delivery of HIV testing and other prevention services to transgender persons. 


\section{Summary}

What is already known about this topic?

Transgender persons are at high risk for HIV infection. CDC recommends that persons at high risk for HIV infection be screened for HIV at least annually, but transgender persons are not specified in the current recommendations, and current nationwide HIV testing rates for transgender persons are unknown.

What is added by this report?

This analysis of 2014 and 2015 Behavioral Risk Factor Surveillance System data showed that transgender women and men self-reported a lower prevalence of HIV testing (both ever and in the past year) compared with gay and bisexual men whose gender identities match their sex assignments at birth (cisgender). Transgender women and men self-reported testing at levels similar to cisgender heterosexual men and women.

What are the implications for public health practice?

Transgender women and men reported current HIV testing levels that were inconsistent with their HIV risk profiles. Innovative, tailored approaches might be needed to reach transgender persons who are not being reached by existing HIV prevention strategies that focus on other key populations, such as gay, bisexual, and other men who have sex with men.

\section{Acknowledgments}

Rashida Dorsey, Rachel Hornstein, and colleagues at the Office of the Assistant Secretary for Planning and Evaluation, U.S. Department of Health and Human Services.

\section{Conflict of Interest}

No conflicts of interest were reported.

\footnotetext{
${ }^{1}$ Division of HIV/AIDS Prevention, National Center for HIV, Viral Hepatitis, STD and TB Prevention, CDC; ${ }^{2}$ Division of Population Health, National Center for Chronic Disease Prevention and Health Promotion, CDC.
}

Corresponding Author: Marc Pitasi, mpitasi@cdc.gov, 404-639-6361.

\section{References}

1. Habarta N, Wang G, Mulatu MS, Larish N. HIV testing by transgender status at CDC-funded sites in the United States, Puerto Rico, and US Virgin Islands, 2009-2011. Am J Public Health 2015;105:1917-25. https://doi.org/10.2105/AJPH.2015.302659

2. Reisner SL, Murchison GR. A global research synthesis of HIV and STI biobehavioural risks in female-to-male transgender adults. Glob Public Health 2016;11:866-87. https://doi.org/10.1080/17441692.2015.1134613

3. CDC. HIV infection risk, prevention, and testing behaviors among men who have sex with men-National HIV Behavioral Surveillance, 20 U.S. cities, 2014. HIV surveillance special report, no 15; Atlanta, GA: US Department of Health and Human Services, CDC; 2016. https:// www.cdc.gov/hiv/pdf/library/reports/surveillance/cdc-hiv-hssr-nhbsmsm-2014.pdf

4. Lansky A, Johnson C, Oraka E, et al. Estimating the number of heterosexual persons in the United States to calculate national rates of HIV infection. PLoS One 2015;10:e0133543. https://doi.org/10.1371/ journal.pone. 0133543

5. Herbst JH, Jacobs ED, Finlayson TJ, McKleroy VS, Neumann MS, Crepaz N; HIV/AIDS Prevention Research Synthesis Team. Estimating HIV prevalence and risk behaviors of transgender persons in the United States: a systematic review. AIDS Behav 2008;12:1-17. https://doi. org/10.1007/s10461-007-9299-3

6. Cooley LA, Wejnert C, Rose CE, et al.; National HIV Behavioral Surveillance Study Group. Increases in recent HIV testing among men who have sex with men coincide with the CDC's expanded testing initiative. Clin Infect Dis 2015;60:483-5. https://doi.org/10.1093/cid/ciu851

7. Yehia BR, Cui W, Thompson WW, et al. HIV testing among adults with mental illness in the United States. AIDS Patient Care STDS 2014;28:628-34. https://doi.org/10.1089/apc.2014.0196

8. Lippman SA, Moran L, Sevelius J, et al. Acceptability and feasibility of HIV self-testing among transgender women in San Francisco: a mixed methods pilot study. AIDS Behav 2016;20:928-38. https://doi. org/10.1007/s10461-015-1236-2

9. Scheim AI, Santos G-M, Arreola S, et al. Inequities in access to HIV prevention services for transgender men: results of a global survey of men who have sex with men. J Int AIDS Soc 2016;19(Suppl 2):20779. https://doi.org/10.7448/IAS.19.3.20779

10. Reback CJ, Ferlito D, Kisler KA, Fletcher JB. Recruiting, linking, and retaining high risk transgender women into HIV prevention and care services: an overview of barriers, strategies, and lessons learned. Int J Transgenderism 2015;16:209-21. https://doi.org/10.1080/15532739 .2015 .1081085 